\title{
'UF Multi-flora Peach' and 'UF Multi-flora Pink Frost' Gerberas - University of Florida Cultivars for Landscapes and Large Pots ${ }^{1}$
}

\section{Zhanao Deng and Brent K. Harbaugh ${ }^{2}$}

Gerbera daisy is an important floricultural crop in the United States and worldwide. Extensive gerbera breeding has been conducted in the Netherlands, the United States, Demark, Germany, Israel, Japan, and other countries. Breeding objectives traditionally have targeted development of new or improved cultivars for production of cut flowers, but breeding gerbera for use as small potted plants (4- to 5-inch-diameter pots) has increased dramatically in the last decade. Interest in using gerberas for the flower garden or landscape and in large patio containers has increased in recent years. Yet, breeders only have begun to target development of plants for this market. Landscapers have had to use cultivars that are bred as cut flowers or pot plants, and these types often do not perform ideally in the landscape. A number of vegetative and floral characteristics seem to be necessary for gerbera plants to survive and perform well in the landscape, including adequate plant vigor and size, appropriate peduncle heights, continuous flowering, and adequate disease resistance.
'UF Multi-flora Peach' (Fig. 1) and 'UF Multi-flora Pink Frost' (Fig. 2) have been selected specifically for garden use (Deng and Harbaugh, 2006). Both cultivars are very vigorous and produce large plants with a continuous supply of flowers in the garden. Although their flowers are not large, the plants display many flowers and buds resulting in as much color as plants with larger, but fewer flowers. In addition, 'UF Multi-flora Peach' has shown intermediate powdery mildew resistance.

\section{Origin}

'UF Multi-flora Peach' and 'UF Multi-flora Pink Frost' were selected from a population of 1500 seedlings grown from seeds donated to the University of Florida by Sunshine State Carnations, Inc. (Hobe Sound, Fla.) Parents are unknown but were the result of 30 years of gerbera breeding in south Florida.

\section{Description}

Mature plants of 'UF Multi-flora Peach' grown in ground beds for 3 months were 29 inches wide (Table 1). The leaves were simple and pinnately

1. This document is ENH1043, one of a series of the Environmental Horticulture Department, Florida Cooperative Extension Service, Institute of Food and Agricultural Sciences, University of Florida. Original publication date June 2006. Visit the EDIS Web Site at http://edis.ifas.ufl.edu.

2. Zhanao Deng, assistant professor, and Brent K. Harbaugh, professor, Gulf Coast Research and Education Center, Cooperative Extension Service, IFAS, University of Florida, Gainesville, FL 32611.

The Institute of Food and Agricultural Sciences (IFAS) is an Equal Opportunity Institution authorized to provide research, educational information and other services only to individuals and institutions that function with non-discrimination with respect to race, creed, color, religion, age, disability, sex, sexual orientation, marital status, national origin, political opinions or affiliations. U.S. Department of Agriculture, Cooperative Extension Service, University of Florida, IFAS, Florida A. \& M. University Cooperative Extension Program, and Boards of County Commissioners Cooperating. Larry Arrington, Dean 
lobed, with deep lobes on the base, medium in the central part and slight at the apice. The flowers were semi-double and $31 / 2$ inches in diameter. The average peduncle height of immature and mature flowers is 14 and 18 inches, respectively. The disc florets were a deep bright yellow and the inflorescence center light yellow. The upper surfaces of the outer ray florets were orange-red diffusing into yellow.

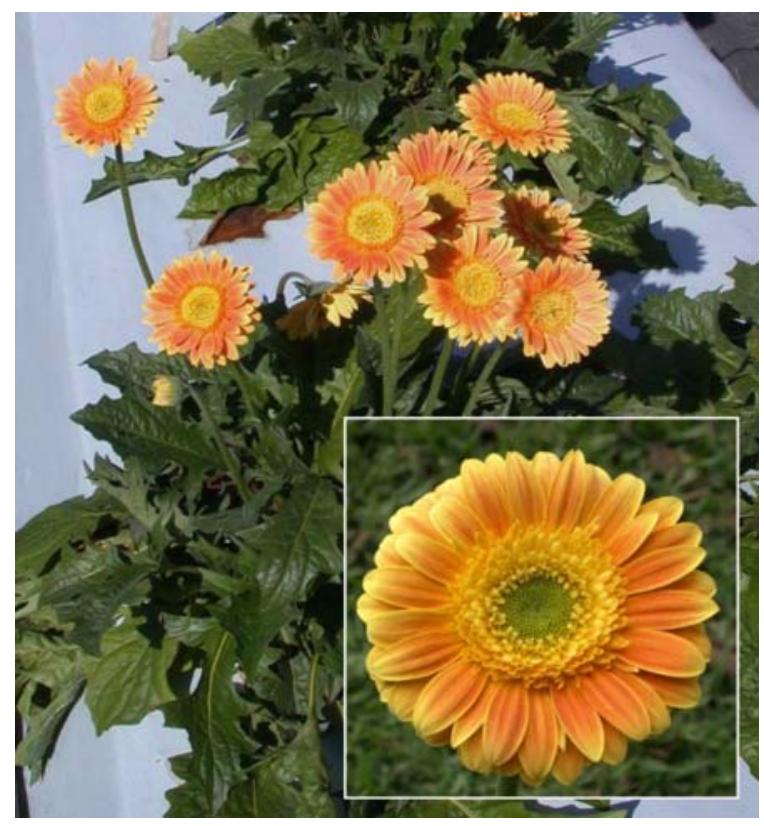

Figure 1. Flowers and plants of 'UF Multi-flora Peach' gerbera grown in a raised bed. Credits: Univ. of Florida/IFAS GCREC

Mature plants of 'UF Multi-flora Pink Frost' grown in ground beds for 3 months were 25 inches wide (Table 1). The leaves were simple and pinnately lobed, with medium deep lobes on the base and very shallow lobing in the central part and the apice. The flowers were semi-double and $31 / 2$ inches in diameter. The average peduncle height of immature and mature flowers is 14 and 17 inches, respectively. The disc florets were similar in color to the ray florets and the inflorescence center was yellow. The upper surfaces of the outer ray florets were red-purple at the base, becoming lighter red-purple near the center, and diffusing into white toward the tip.

\section{Container and Garden Performance}

Plant growth and flowering of 'UF Multi-flora Peach' and 'UF Multi-flora Pink Frost' were compared to 'Revolution Formula Mix' and 'Louisville'. 'Revolution Formula Mix' is a popular



Figure 2. Flowers and plants of 'UF Multi-flora Pink Frost' gerbera grown in a raised bed. Credits: Univ. of FloridalFAS GCREC

seed-propagated cultivar known for early production of many flowers. It is typically grown for market in 5 -inch containers. 'Louisville' is a multi-floral cut-flower type that also is used in the landscape. Standard cut flowers produce flowers 4 to $51 / 2$ inches in diameter, whereas seed and multi-floral types are smaller, generally $21 / 2$ to $31 / 2$ inches in diameter. 'UF Multi-flora Peach' and 'UF Multi-flora Pink Frost' have multi-floral-size flowers. Plants were evaluated in pots to determine flowering potential before marketing. Early flowering in pots is an important characteristic even for garden types of gerbera since they are sold in flower to be transplanted into ground beds later.

Tissue culture liners or seeded plugs ('Revolution Mix' only) were transplanted into 8-inch pots on 14 June, 2004 and grown in a glass greenhouse with approximately $30 \%$ shade. A peat/vermiculite mix (Vergo Container Mix A) was used and plants were top dressed with Osmocote $18 \mathrm{~N}-2.6 \mathrm{P}-10 \mathrm{~K}$ controlled release fertilizer at one teaspoon per pot. The growing area was shaded with $30 \%$ polypropylene shade cloth. The soil was an EauGallie fine sand with about $1 \%$ organic matter and a $\mathrm{pH}$ of 6.2. Plants were grown in a plastic-mulched, raised-bed system. Osmocote $15 \mathrm{~N}-3.9 \mathrm{P}-10 \mathrm{~K}$ controlled-release fertilizer was applied to the bed surface around each plant at four teaspoons per plant. 
'Revolution Formula Mix' produced

significantly more flowers in pots (average of 10 flowers per plant) than the other cultivars (three to four flowers per plant) (Table 1). After transplanting into the field, 'UF Multi-flora Peach' and 'UF Multi-flora Pink Frost' produced nearly twice as many flowers ( 22 to 25 per plant) by the end of the test than the other cultivars (11 to 13 flowers per plant). This attribute, continual flowering over a long period, is essential if the cultivar is to be successful in the garden or landscape. 'Revolution Mix' produced few new flowers after 3 November, while 'UF Multi-flora Peach' and 'UF Multi-flora Pink Frost' continued to produce many flowers late in the season (Fig. 3).

Plant width was greatest for 'UF Multi-flora Peach' and 'Louisville' and intermediate for 'UF Multi-flora Pink Frost'. Seed-propagated varieties often lack vigor and do not grow to adequate sizes in the garden or big containers (Channel, 2005). This was true with 'Revolution Mix', which reached only $\sim 75 \%$ of the plant width (or $\sim 50 \%$ of the plant-covered area) of 'UF Multi-flora Peach' and 'Louisville'.

'UF Multi-flora Peach' was rated the highest (4.8 and 5.0) in plant (leaf) quality, followed by 'UF Multi-flora Frost Pink' (4.2 and 3.0). Plants of 'Louisville' and 'Revolution Mix' performed poorly (1 to 2.2) in both ratings (23 October and 3 November, 2004). This difference in plant performance was to a major extent due to their resistance level to powdery mildew. 'UF Multi-flora Peach' had the lowest powdery mildew severity ratings (3.2 and 3.4) at both rating periods, and thus the greatest level of resistance. 'UF Multi-flora Pink Frost' had higher powdery mildew severity ratings and was more susceptible than 'UF Multi-flora Peach' but still less susceptible than 'Louisville' or 'Revolution Mix', which had almost $100 \%$ of their leaf areas covered with powdery mildew and reached a score of 10 .

In summary, 'UF Multi-flora Peach' and 'UF Multi-flora Pink Frost' are intended for use in the landscape or for large containers. They produce many flowers over an extended period, making them ideal for garden use.

\section{Availability}

Production of this cultivar is to be with a licensing agreement with the Florida Foundation Seed Producers, Inc., P.O. Box 309, Greenwood, F1 32443. Information on availability and propagation agreements can be obtained from the Florida Foundation Seed Producers, Inc.

\section{Literature cited}

Channel, C. 2005. Gerbera trials rate plants. GM Pro 25:30-31.

Deng, Z. and B.K. Harbaugh. 2006. 'UF Multi-flora Peach' and 'UF Multi-flora Pink Frost': Multi-flora gerbera cultivars for landscapes and large pots. HortScience 41:843-845.

Hausbeck, M.K., W.R. Quackenbush, and N.A. Werner. 2002. Evaluation of fungicides for control of powdery mildew of transvaal daisy, 2001. F\&N Tests 57:OT27. 


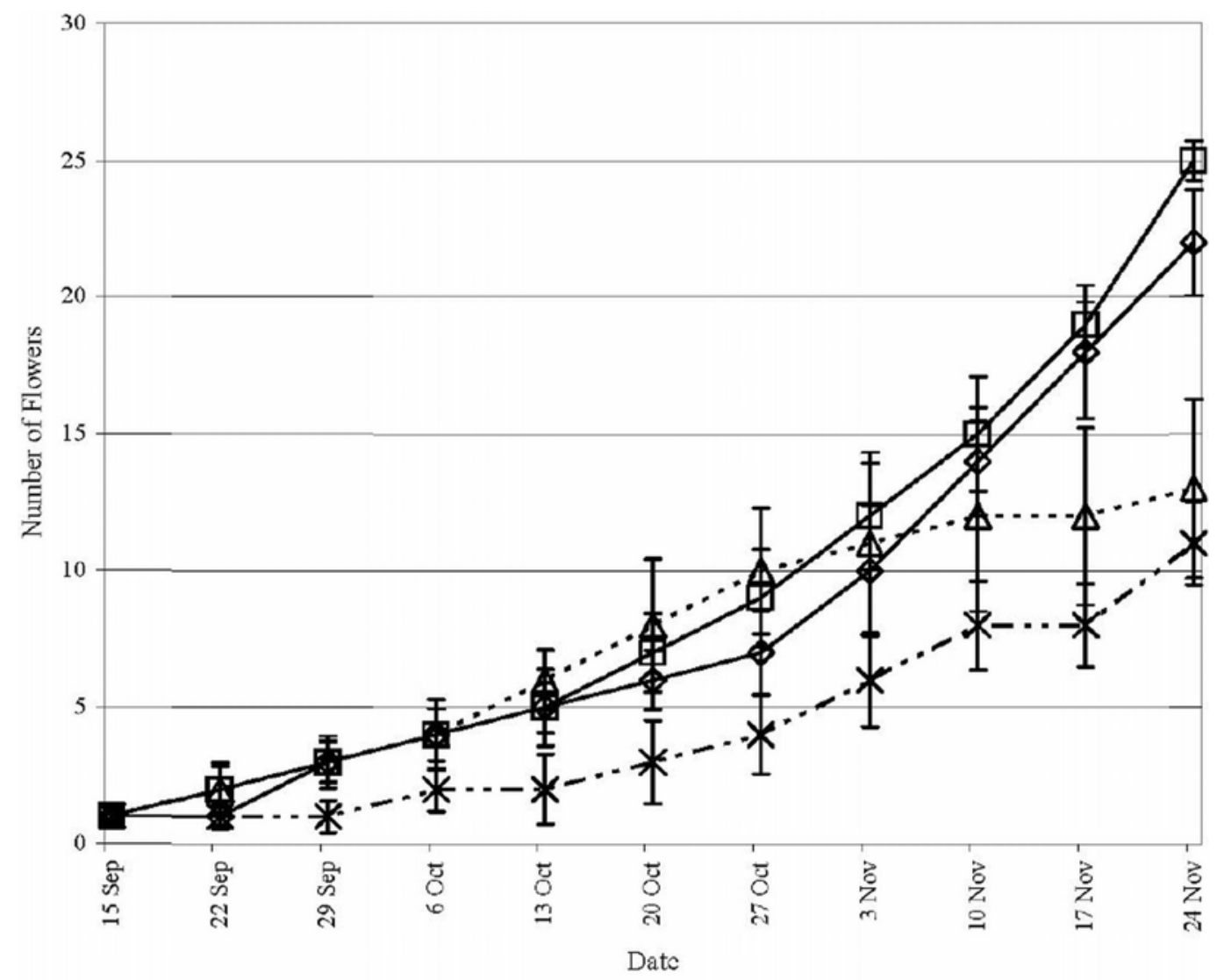

'UF Multi-flora Peach' ( $\square)$, 'UF Multi-flora Pink Frost' $(\diamond)$, 'Louisville' $(\Delta)$, and 'Revolution Formula Mix' $(\times)$

Figure 3. Cumulative number of flowers produced per plant of four cultivars, over 10 weeks from 15 Sept. to 24 Nov. 2004 in flower beds in Bradenton, FL. Each value represents the mean of 4 replications with 3 plants per replication. Credits: Univ. of Florida/IFAS GCREC 


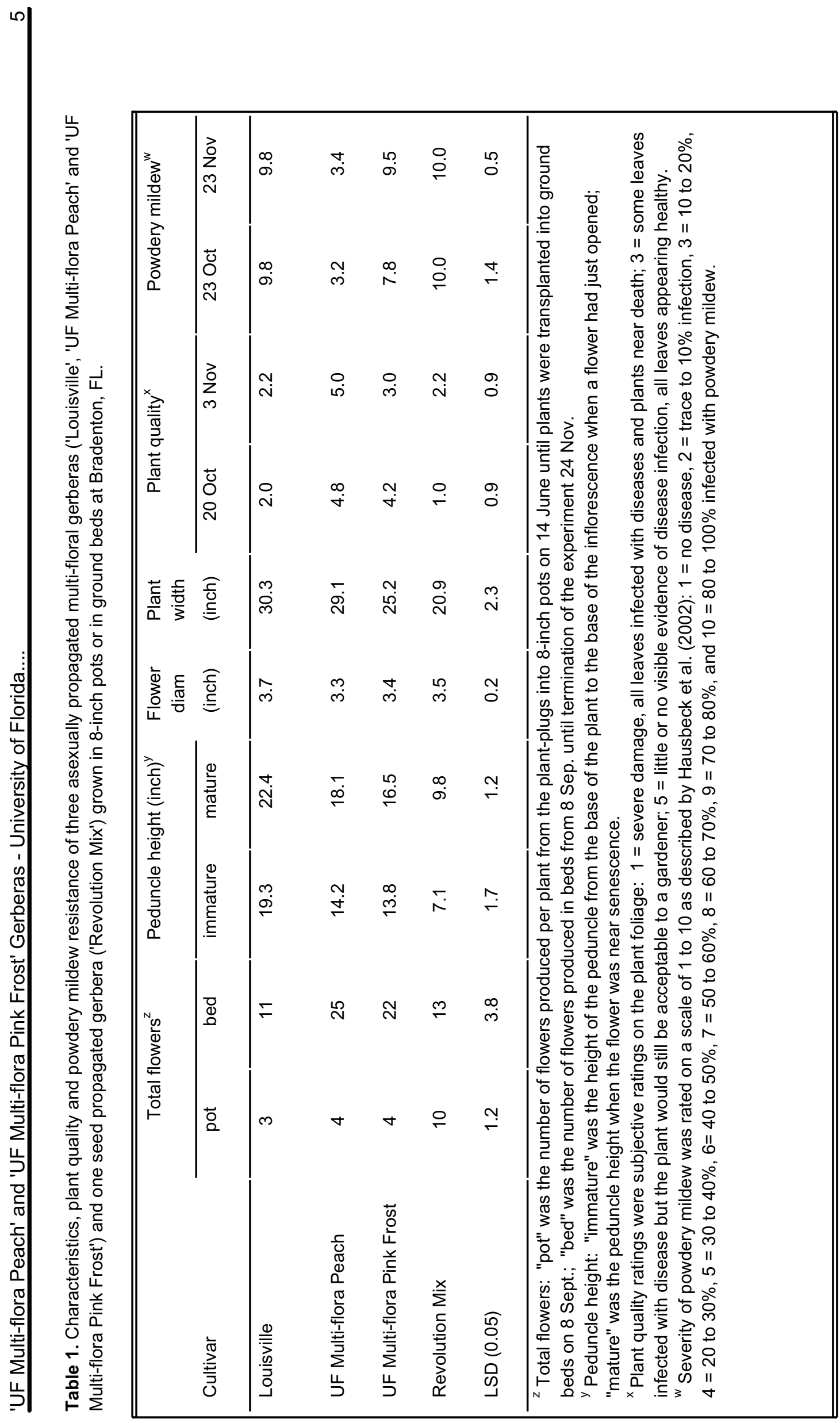

